\title{
일본의 $\mathrm{ODA}$ 동향 \\ (JBIC 엔차관 부문의 JICA로의 통합)
}

일본 정부 및 자민당은 일본 정부산하 금융기관 통폐합 논의 과정에서 엔차관 등 국제협력은행 (JBIC)의 ODA 기능을 국제협력기구(JICA)로 통합 하는 방안을 검토 중인 바, 관련 사항은 아래와 같음.
담을 축소시키기 위한 목적

동ㅇ 구체 개혁방안에 대해 현재 총리 산하 경제재 정자문회의 및 자민당에서 8 개 기관을 단일기관 으로 통합하는 방안 및 업무특성에 따라 3 개 기관 으로 통합하는 방안을 놓고 검토중

\section{JBIC의 JICA로의 통합}

ㅁ 고이즈미 총리가 일본 구조개혁의 핵심사업으로 추진해 온 우정 민영화법이 지난 10 월 국회를 통 과함에 따라 정부산하 금융기관 개혁이 고이즈미 개혁의 차기 주요과제로 부상함.

- 동 개혁은 국제협력은행(JBIC) 및 일본정책투자 은행, 상공조합중앙금고, 국민생활금융공고(公 庫), 중소기업금융공고, 농림어업금융공고, 오 키나와진흥개발금융공고 등 8개 정부계 금융기 관의 민영화 및 통폐합을 통해 정부재정에의 부
ㅁ 상기와 같이 현재 검토되고 있는 1 개 기관안 및 3 개 기관안은 국제협력은행(JBIC)의 존속여부에 대해 상반된 입장을 제시

-3 개 기관안의 경우 국제협력은행 존속(대기업에 대한 투자금융 업무를 일부 축소시키나 ODA 부문은 유지)

-1 개 기관안의 경우 국제협력은행의 투자금융 등 업무는 새로이 탄생하는 정부금융기관에 업무 를 이관하고, $\mathrm{ODA}$ 업무는 정부계 금융기관이 
아닌 JICA 등 일반 정부기관으로 이전

ㅁ상기와 관련, 11 월 22 일자 닛케이 신문은 총리 산 하 경제재정자문회의가 정부계 금융기관 개혁의 기본지침안을 마련한 바, $\mathrm{JBIC}$ 의 엔차관 부문을 $\mathrm{JICA}$ 로 통합하여 외무성 관리하 또는 총리 직할 로 하는 방안 등을 검토하기로 하였다고 보도함.

\section{III. 향후 일정 및 전망}

일본 정부는 이달말까지 정부계금융기관 통폐합 방안 기본방침을 결정할 예정이며, 이에 기초하여 2008년까지 실제 민영화 및 통폐합 작업을 진행 할 예정
동 구체 방안과 관련하여 고이즈미 총리가 수차례 1 기관 통합안 지지를 표명한 바 있는 가운데 자민 당 내에서도 1 기관 통합방안이 우세한 것으로 알 려지고 있어 1 개 기관안이 채택될 가능성이 높은 것으로 전망됨.

- 이 경우 국제협력은행의 ODA 부문은 JICA로 통합될 것으로 전망

단, 1 개 기관 통합안에 대해 재무성, 경산성 등 일 본 정부 각 부처가 반발하고 있어, 실제 방향은 이 달말 정부 기본방침이 결정되어야 알 수 있을 것 으로 보여짐.

[자료:주일본 대사관] 